\title{
Pengaruh angka harapan hidup, rata-rata lama sekolah dan pengeluaran perkapita terhadap tingkat kemiskinan pada Kabupaten /Kota di Provinsi Jambi
}

\author{
Ropikatul Hasanah*; Syaparuddin; Rosmeli
}

\author{
Prodi Ekonomi Pembangunan, Fak. Ekonomi dan Bisnis, Universitas Jambi \\ *E-mail korespondensi: rafikahasanah@gmail.com
}

\begin{abstract}
This study aims to analyze the development of life expectancy, the average length of schooling, expenditure per capita, and poverty level in districts/cities in Jambi Province, as well as analyze the effect of life expectancy, the average length of schooling, and expenditure per capita on poverty levels. The analytical method used is panel data regression. The results of this study indicate that. After the Chow and Hausmant test, the best model is the Fixed effect. Partially, the analysis results of the variable life expectancy and expenditure per capita significantly impact the poverty level. At the same time, the average length of school does not have a significant effect. Simultaneously, life expectancy, the average schooling size, and per capita expenditure significantly impact poverty levels in districts/cities in Jambi province
\end{abstract}

Keywords: Poverty, Life expectancy, Length of schooling, Expenditure per capita

\begin{abstract}
Abstrak
Penelitian ini bertujuan untuk menganalisis perkembangan angka harapan hidup, rata-rata lama sekolah, pengeluaran per kapita dan tingkat kemiskinan pada Kabupaten/Kota di Provinsi Jambi, serta menganalisis pengaruh angka harapan hidup, rata-rata lama sekolah, dan pengeluaran per kapita terhadap tingkat kemiskinan. Metode analisis yang digunakan adalah regresi data panel. Hasil dari penelitian ini menunjukan bahwa. Model yang terbaik setelah dilakukan uji Chow dan uji Hausmant adalah Fixed effect. Secara parsial Hasil analisis variabel angka harapan hidup dan pengeluaranperkapita berpengaruh signifikan terhadap tingkat kemiskinan. Sedangkan rata-rata lama sekolah tidak berpengaruh signifikan. Secara simultan angka harapan hidup, lama-lama rata sekolah dan pengeluaran perkapita secara bersama-sama berpengaruh signifikan terhadap tingkat kemiskinan di Kabupaten/Kota di Provinsi Jambi.
\end{abstract}

Kata kunci: Kemiskinan, Angka harapan hidup, Lama sekolah, Pengeluaran perkapita

\section{PENDAHULUAN}

Kesejahteraan merupakan suatu keadaan terpenuhinya kebutuhan dasar yang terlihat dari rumah yang layak, tercukupinya kebutuhan akan sandang (pakaian) dan pangan (makanan), pendidikan dan kesehatan, atau keadaan dimana seseorang mampu memaksimalkan utilitasnya pada tingkat batas anggaran tertentu dan kondisi dimana tercukupinya kebutuhan jasmani dan rohani (Todaro dan Stephen C.smith (2006). Terdapat tiga dimensi dari ukuran kualitas hidup manusia yakni pertama dimensi kesehatan, kedua dimensi pendidikan dan yang ketiga adalah standar hidup layak. Dalam cakupan lebih luas standar hidup layak menggambarkan tingkat kesejahteraan yang dinikmati oleh penduduk sebagai dampak semakin membaiknya ekonomi. Chaudhry (2009)

Kemiskinan merupakan salah satu persoalan yang menjadi pusat perhatian pemerintah terutama di negara sedang berkembang seperti Indonesia, sehingga menjadi 
suatu fokus yang sangat penting bagi pemerintah Indonesia. Kemiskinan telah membatasi kesempatan masyarakat untuk mendapatkan haknya sebagai manusia untuk memperoleh akses kebutuhan hidup (pangan,sandang,papan). Masalah kemiskinan memilih banyak dimensi seperti hal nya dimensi sosial dan dimensi ekonomi. Dimensi sosial berhubungan dengan stratifikasi sosial atau pembedaan lapisan masyarakat antara yang kaya dan miskin, sedangkan dimensi ekonomi berhubungan dengan pendapatan individu dan perekonomian suatu negara. Jumlah penduduk miskin di Indonesia pada periode 20112019 cenderung mengalami penurunan, meskipun terjadi peningkatan jumlah penduduk miskin di Indonesia di tahun 2015 yakni 28,51 juta jiwa di mana di tahun 2014 berjumlah 27,73 juta jiwa (BPS, 2020).

Jumlah penduduk miskin di Provinsi Jambi menurut BPS dari tahun 2014-2019 mengalami fluktuasi, pada tahun 2014 jumlah penduduk miskin di Provinsi Jambi adalah 281,75 ribu jiwa kemudian naik pada tahun 2015 menjadi 300,71 ribu jiwa, turun menjadi 289,81 ribu jiwa pada tahun 2016 kemudian mengalami penurunan hingga tahun 2019 yaitu sebesar 274,32 ribu jiwa (BPS, 2020).

Dari aspek ekonomi pada Kabupaten/Kota di Provinsi Jambi telah menunjukkan pertumbuhan yang cukup tinggi. Pertumbuhan tersebut dicerminkan oleh PDRB yang telah dicapai baik di Provinsi maupun per kabupaten/kota. Provinsi Jambi terdapat 11 kabupaten/kota sebagai daerah otonom, di mana setiap daerah memiliki perbedaan karakteristik, kondisi demografi, infrastruktur dan sumber daya alam, perbedaan tersebut menyebabkan tingkat kesejahteraan pada masing - masing daerah juga berbeda, yang sangat dipengaruhi oleh sumber potensi yang dimiliki masing - masing daerah, dan pada akhirnya akan menimbulkan implikasi yang berbeda terhadap tingkat kemiskinan pada Kabupaten/Kota Provinsi Jambi tersebut.

Kinerja kabupaten/kota dalam menurunkan angka kemiskinan dalam rentang waktu antara tahun 2015 hingga tahun 2019 dalam mengurangi angka kemiskinan tercatat cukup optimal namun masih ada peningkatan di beberapa tahun, hampir semua Kabupaten/Kota di Provinsi Jambi mengalami penurunan tingkat kemiskinan per tahunnya, kecuali pada tahun 2015 yang mengalami peningkatan, selanjutnya daerah dengan tingkat kemiskinan terbanyak adalah Kabupaten Tanjung Jabung Timur.

Menurut Sharp (dalam Kuncoro, 2010), terdapat tiga faktor penyebab kemiskinan. Salah satu faktor penyebab kemiskinan adalah rendahnya sumber daya manusia yang disebabkan karena rendahnya pendidikan. Pendidikan merupakan kebutuhan paling asasi bagi semua orang karena masyarakat yang berpendidikan setidaknya dapat memiliki kemampuan untuk membebaskan diri dari kemiskinan. Tingkat pendidikan dapat digunakan sebagai salah satu indikator untuk melihat tingkat kesejahteraan penduduk. Semakin tinggi tingkat pendidikan seseorang, semakin baik pula kualitas sumber daya manusianya. Pendidikan sebagai faktor terpenting yang dapat membuat seseorang keluar dari kemiskinan. Keterkaitan kemiskinan dan pendidikan sangat besar karena pendidikan memberikan kemampuan untuk berkembang lewat penguasaan ilmu dan keterampilan (Suryawati, 2015). Pendidikan dalam penelitian ini dilihat dari rata-rata lama sekolah. Indikator rata-rata lama sekolah dimanfaatkan untuk melihat kualitas penduduk berdasarkan pendidikan formal yang diselesaikan. Semakin tinggi tingkat pendidikan seseorang, maka pengetahuan dan keahlian juga akan meningkat sehingga akan mendorong peningkatan produktivitas seseorang. Pendidikan (formal dan non formal) bisa berperan penting dalam menggurangi kemiskinan dalam jangka panjang, baik secara tidak langsung melalui perbaikan produktivitas dan efesiensi secara umum, maupun secara langsung melalui pelatihan golongan miskin dengan keterampilan yang dibutuhkan untuk meningkatkan produktivitas mereka dan pada gilirannya akan meningkatkan pendapatan mereka. (Arsyad, 2016).

Faktor lain yang juga berpengaruh terhadap tingkat kemiskinan menurut Suryawati (2015) adalah kesehatan. Masalah kesehatan merupakan hal yang rentan 
dihadapi oleh masyarakat miskin, hal ini diakibatkan karena keterbatasan ekonomi mereka dalam upaya mempersehat diri dan memenuhi kebutuhan masing-masing. Tingkat kesehatan akan sangat berpengaruh terhadap tingkat kesejahteraan masyarakat dan memiliki keterkaitan yang erat dengan kemiskinan. Kemudian pengeluaran per kapita juga berpengaruh terhadap tingkat kemiskinan, semakin tinggi pengeluaran menunjukkan semakin tinggi tingkat daya beli/konsumsi masyarakat yang menandakan kesejahteraan masyarakat semakin membaik.

Angka harapan hidup Provinsi Jambi pada tahun 2015 adalah 70,56 tahun, kemudian terus meningkat hingga pada tahun 2019 menunjukkan angka 71,06 tahun. Angka tersebut cukup besar, dimana hal itu berarti rata-rata perkiraan banyak tahun yang dapat ditempuh oleh seseorang selama hidup cukup tinggi dan juga tingkat kesehatan masyarakat Provinsi Jambi dinilai cukup baik dan diharapkan terus meningkat setiap tahunnya. Rata-rata lama sekolah di Provinsi Jambi tahun 2011 adalah 7,48, tahun 2012 7,69, kemudian tahun 2013 adalah 7,80 dan tahun 2014 adalah 7,92, lalu tahun 2015 sebesar 7,96, tahun 2016 dan terus menigkat pada tahun 2019 sebesar 8,45 tahun (BPS, 2021). Secara rata-rata penduduk Provinsi Jambi yang berusia 15 tahun atau lebih menyelesaikan pendidikan selama 7,75 tahun.

Meningkatnya indeks pembangunan manusia dari angka harapan hidup, rata-rata lama sekolah dan pengeluaran perkapita akan menunjukan penurunan tingkat kemiskinan di Provinsi Jambi, sehingga berdasarkan uraian tersebut, penulis tertarik untuk mencoba mengidentifikasi dan menganalisis masalah, adapun tujuan dalam penelitian ini adalah untuk mengetahui kondisi angka harapan hidup, rata-rata lama sekilah, pengeluaran perkapita dan tingkat kemiskinan. Serta untuk mengetahui dan menganalisis pengaruh angka harapan hidup, rata-rata lama sekolah, pengeluaran perkapita terhadap tingkat kemiskinan pada Kabupaten/Kota di Provinsi Jambi

\section{METODE}

Penelitian ini menggunakan data sekunder, dalam bentuk panel data. Data yang digunakan berupa angka harapan hidup, rata-rata lama sekolah, pengeluran perkapita serta tingkat kemiskinan yang bersumber dari Badan Pusat Statistik (BPS) Provinsi Jambi.

Untuk menjawab tujuan pertama digunakan metode analisis deskiptif merupakan suatu analisis secara kualitatif tehadap kondisi dari data-data yang ada untuk memperkuat analisis empirik (Junaidi, 2015). Permasalahan kedua dianalisis dengan menggunakan regresi data panel dengan model persamaan sebagai berikut (Endri, 2011):

$Y_{i t}=\beta_{0}+\beta_{1} X_{i t}+u_{i} \ldots \ldots . . ., N ; t=1,2, \ldots . ., t$

Kemudian diaplikasikan dalam penelitian menjadi:

$$
\mathrm{TK}_{\mathrm{it}}=\beta_{0}+\beta_{1} \mathrm{AHH}_{\mathrm{it}}+\beta_{2} \mathrm{RLS}_{\mathrm{it}}+\beta_{3} \mathrm{PP}_{\mathrm{it}}+\mathrm{u}_{\mathrm{i}}
$$

Keterangan:

$$
\begin{array}{ll}
\text { TK } & \text { : Tingkat kemiskinan } \\
\text { AHH } & \text { : Angka harapan hidup } \\
\text { RLS } & \text { : Rata-rata lama sekolah } \\
\text { PP } & \text { : Pengeluaran per kapita } \\
\beta_{0} & : \text { Intersep } \\
\beta_{1}, \beta_{2}, \beta_{3} & : \text { Koefisien regresi } \\
\mathrm{t} & : \text { Tahun } \\
\mathrm{u}_{\mathrm{i}} & \text { : Komponen error di waktu } \mathrm{t}
\end{array}
$$

\section{Uji spesifikasi model}


Sebelum melakukan regresi, langkah yang dilakukan adalah melakukan pengujian estimasi model untuk memperoleh estimasi model yang paling tepat digunakan. Untuk melakukan model mana yang akan dipakai, maka dilakukan pengujian diantarnya :

\section{Uji Chow (uji common effect dengan fixed effect)}

Uji ini digunakan untuk mengetahui apakah teknik regresi data panel dengan metode Fixed Effect lebih baik dari regresi model data panel tanpa variabel dummy atau metode Common Effect. Hipotesis yang digunakan adalah sebagai berikut :

$\mathrm{H}_{0} \quad$ : maka digunakan model Common Effect (model pool)

$\mathrm{H}_{1} \quad$ : maka digunakan model Fixed Effect dan lanjut Uji Hausman.

Apabila hasil uji Chow ini menghasilkan probabilitas ChiSquare lebih dari 0,05 maka model yang digunakan adalah model common effect. Sebaliknya, apabila probabilitas Chi-Square yang dihasilkan kurang dari 0,05 maka model yang sebaiknya digunakan adalah model fixed effect. Pada saat model yang terpilih adalah fixed effect maka diperlukan uji Hausman.

\section{Uji Hausman (uji fixed effect dengan random effect)}

Uji Hausman digunakan untuk mengetahui uji mana yang terbaik antara random effect dan fixed effect. Untuk menguji Hausman Test data juga diregresikan dengan model random effect, kemudian dibandingkan antara fixed effect dan random effect dengan membuat hipotesis:

$\mathrm{H}_{0} \quad$ : maka digunakan model Random Effect

$\mathrm{H}_{1} \quad$ : maka digunakan model Fixed Effect

Apabila nilai probabilitas kurang dari taraf signifikansi 5\% $(0,05)$ maka model yang digunakan adalah fixed effect model dan jika nilai probabilitas lebih dari taraf signifikansi 5\% maka model yang digunakan adalah random effect model.

\section{Uji lagrange multiplier (LM)}

Uji LM digunakan apabila uji chow mendapatkan hasil fixed effect dan uji hausment mendapatkan hasil rendom effect, maka dilakukan uji lagrange untuk mengetahui common effect dengan rendom effect. Apabila nilai LM hitung lebih besar dari nilai kritis Chi-Squares maka hipotesis nul ditolak yang artinya model yang tepat untuk regresi data panel adalah model Random Effect. Dan sebaliknya, apabila nilai LM hitung lebih kecil dari nilai kritis Chi-Squares maka hipotesis nul diterima yang artinya model yang tepat untuk regresi data panel adalah model Common Effect.

\section{Uji asumsi klasik}

Basuki (2016) dalam data panel untuk uji asumsi klasik hanya uji Multikolinearitas dan uji Heterokedastisitas. Sedang uji Linearitas, Normalitas dan Autokorelasi tidak.

\section{Uji hipotesis}

Uji hipotesis yang digunakan dalam penelitian ini adalah Uji t (uji parsial) dan uji $\mathrm{F}$ (uji simultan). Uji $\mathrm{t}$ digunakan untuk melihat pengaruh masing-masing variabel bebas terhadap variabel terikat. Uji F digunakan untuk melihat pengaruh variabel berbas secara bersama-sama terhadap variabel terikat.

\section{Koefisien determinasi $\left(\mathbf{R}^{2}\right)$}


Digunakan untuk mengukur pengaruh variabel independen secara kuat terhadap variabel dependen Nilai $\mathrm{R}^{2}$ yang mendekati satu berarti variabel-variabel bebas memberikan hampir semua informasi yang dibutuhkan untuk memprediksi variabel-variabel terikat.

\section{HASIL DAN PEMBAHASAN}

\section{Kondisi angka harapan hidup Kab/Kota di Provinsi Jambi}

Komponen kesehatan merupakan komponen yang penting sebagai salah satu bentuk keadaan kualitas manusia di Kabupaten / Kota di Provinsi Jambi. Peningkatan dan perbaikan derajat kesahatan dapat terlihat dari peningkatan umur harapan hidup atau angka harapan hidup manusia. Semakin sehat seseorang atau semakin tinggi akan kesadaran sehat manusia maka semakin tinggi angka harapan hidup manusia atau dapat memperpanjang usia harapan hidup manusia. Angka harapan hidup manusia di Kabupaten/ Kota di Provinsi Jambi mengalami peningkatan pada periode 2015 hingga 2019. Rata-rata angka harapan hidup di Kabupaten /Kota di Provinsi Jambi berada di usia 65 tahun ke atas. Kota Jambi merupakan Kab/Kota yang memiliki nilai rata-rata angka harapan hidup paling tinggi diantara Kabupaten Lainnya yaitu sebesar 72,35 tahun, artinya di Kota Jambi rata-rata perkiraan banyak tahun yang ditempuh masyarakat di Kota Jambi periode 2015 sampai 2019 yaitu 72 tahun. Sehingga dapat disimpulkan bahwa derajat kesehatan penduduk di Kabupaten/ Kota di Provinsi Jambi cukup baik.

\section{Kondisi rata-rata lama sekolah Kab/Kota di Provinsi Jambi}

Rata-rata lama sekolah di Kabupaten/Kota di Provinsi Jambi periode 2015 sampai 2019 mengalami peningkatan dengan rata-rata lama sekolah tertinggi adalah di Kota Jambi, dengan jumlah rata-rata 10,70 per tahun. Ini menunjukan bahwa dari tahun ketahun periode 2015 hingga 2019 rata-rata lama sekolah di Kota Jambi perkembanganya mengalami peningkatan yang baik. Sedangkan jumlah rata-rata lama sekolah terendah di Kabupaten Tanjung Jabung Timur yaitu sebesar 6,32 per tahun. Artinya rata-rata jumlah tahun yang dihabiskan oleh penduduk usia 15 tahun keatas di jenjang pendidikan formal di Kabupaten Tanjung Jabung Timur yaitu sekitar 7 tahun. Sehingga rata-rata diantara tahun 2015 hinga 2019 di Kabupaten Tanjung Jabung Timur hanya menamatkan sekolah SD dan memasuki SMP. Kab/Kota di Provinsi Jambi yang memiliki nilai rata-rata lama sekolah tertinggi adalah Kota Jambi yaitu 10,70 tahun. artinya sekitar 11 tahun penduduk usia 15 tahun keatas di Kota Jambi mengemban pendidikan formal hingga SMA. Tingginya nilai rata-rata lama sekolah di Kota Jambi didukung karena Kota Jambi merupakan ibu kota di Provinsi Jambi, sehingga penyebaran rata-rata lama sekolah cukup tinggi dibandingkan dengan Kab/Kota lainnya.

\section{Kondisi pengeluaran per kapita Kab/Kota di Provinsi Jambi}

Nilai pengeluaran per kapita di Kab/Kota di Provinsi Jambi periode tahun 2015 sampai 2019 menglamai peningkatan, artinya kemampuan daya beli masyarakat untuk memenuhi kebutuhan pokoknya mengalami peningkatan dengan rata-rata pengeluaran per kapita pertahunya diantara 9.000.000 Rupiah sampi dengan lebih dari 11.000.000 Rupiah. Rata-rata pengeluaran per kapita paling besar di Kota Jambi dengan rata-ratanya sebesar 11.618.380 Rupiah, berarti Kota Jambi merupakan Kab/Kota yang memiliki pengeluaran per kapitanya cukup tinggi di Provinsi Jambi, daya beli masyarakat meningkat dari tahun ketahun di Kota Jambi.

\section{Kondisi tingkat kemiskinan Kab/Kota di Provinsi Jambi}


Tingkat kemiskinan di Kab/Kota di Provinsi Jambi mengalamai penurunan periode tahun 2015-2019. Rata-rata tingkat kemiskinan terendah pada tahun 2015 hingga 2019 terjadi di Kota Sungai Penuh dengan rata-rata tingkat kemiskinannya sebesar 2,98 persen. Hal ini disebabkan karena Kota Sungai penuh merupakan kota baru dari pemekaran Kabupaten Kerinci pada tahun 2009, dan memiliki jumlah penduduk yang paling sedikit dibandingkan Kab/Kota di Provinsi Jambi lainnya (Sungaipenuhkota.go.id, 2021). Sehingga tingkat kemiskinan di Kota Sungai Penuh paling sedikit dibandingkan $\mathrm{Kab} /$ Kota lainnya. Secara keseluruhan dari $11 \mathrm{Kab} /$ Kota yang ada rata-rata tingkat kemiskinan tertinggi berada di Kabupaten Tanjung Jabung Timur dan Tanjung Jabung Barat dengan persentase tingkat kemiskinannya sebesar 12,69 persen untuk Kabupaten Tanjung Jabung Timur dan 11,48 persen di Kabupaten Tanjung Jabung Barat. Berdasarkan penelitian Anggoro (2020) kemiskinan di Kabupaten Tanjung Jabung Timur paling banyak di jumpai pada petani dan nelayan yang merupakan 69,34 persen dari angkatan kerja. Ini disebabkan karena petani pangan biasanya hanya menghasilkan panen satu kali dalam satu tahun dan nelayan yang hanya mampu menangkap ikan tanpa adanya pergerakan untuk memanfaatkan sumberdaya laut yang ada. Selain itu kekurangan modal, rendahnya produktivitas dan lemahnya penguasaan teknologi menyebabkan Kabupaten Tanjung Jabung Timur dan Barat memiliki tingkat kemiskinan yang tinggi dibandingkan $\mathrm{Kab} /$ Kota lainnya.

\section{Uji estimasi regresi data panel (uji chow)}

Hasil Uji Chow menunjukkan bahwa nilai probabilitas cross section sebesar 0,0000 , dimana nilai tersebut lebih kecil dari taraf $\alpha=5 \%(0,0000<\alpha)$. Ini berarti $H_{0}$ ditolak dan model terbaik dalam penelitian ini adalah fixed effect model.

\section{Uji hausmant}

Hasil uji Hausman menunjukkan bahwa nilai probabilitas cross section random sebesar 0,0000 , dimana nilai tersebut lebih kecil dari taraf $\alpha=5 \%(0,0000<\alpha)$. Ini berarti $H_{0}$ ditolak dan model terbaik dalam penelitian ini adalah fixed effect model.

Dari hasil estimasi, diperoleh model terbaik dalam penelitian ini adalah fixed effect model sehingga dilanjutkan dengan regresi data dengan mengunakan fixed effect model pada Tabel 1.

Tabel 1. Fixed effect model

\begin{tabular}{crrrr}
\hline Variable & Coefficient & Std. Error & t-Statistic & Prob. \\
\hline C & 65.56900 & 20.96424 & 3.127660 & 0.0032 \\
AHH? & -0.777935 & 0.324464 & -2.397603 & 0.0211 \\
RLS? & -0.248954 & 0.272014 & -0.915224 & 0.3654 \\
PP? & -0.000137 & $3.29 \mathrm{E}-05$ & -4.168058 & 0.0002 \\
R-squared & 0.991940 & & & \\
F-statistic & 388.1509 & & & \\
Prob(F-statistic) & 0.000000 & & & \\
\hline
\end{tabular}

Sumber: Data diolah, 2021

Model dengan persamaan yang diperoleh:

$T K_{i t}=65,56900-0,777935 A H H_{i t}-0,248954 R L S_{i t}-0,000137 P P_{i t}$

Uji hipotesis (uji t- statistik) 
Variabel angka harapan hidup menunjukkan nilai koefisien sebesar $-0,777935$ dengan nilai probabilitas 0,0211 atau lebih kecil dari $\alpha=5 \%(0,0211<0,05)$, dengan $\mathrm{t}$ statistik sebesar 2,39763 yang lebih besar dari t tabel 1,675 maka $H_{0}$ ditolak dan $H_{a}$ diterima yang mengindikasikan bahwa variabel angka harapan hidup berpengaruh signifikan terhadap tingkat kemiskinan di Kab/Kota di Provinsi Jambi. Tanda koefisien bernilai negatif, artinya ketika terjadi kenaikan angka harapan hidup sebesar 1 tahun, maka tingkat kemiskinan turun sebesar 0,777935 persen. Hasil ini sesuai dengan teori yang dikemukakan oleh Anggadini (2015), menyatakan bahwa angka harapan hidup berpengaruh negatif dan signifikan terhadap tingkat kemiskinan. Indikator dalam melihat perkembangan kesehatan salah satunya adalah angka harapan hidup. Dimana kondisi dikatakan sehat apabila mental maupun sosial nya baik, sehat bukan hanya dari ketidakadaan penyakit tetapi juga kemampuan manusia dalam mengembangkan potensinya, sehingga sehat merupakan sumber penting dalam kesejahteraan. Meningkatnya kesehatan atau angka harapan hidup akan memperpanjang masa kerja dan meningkatkan kualitas daya tahan tubuh yang selanjutnya akan meningkatkan output yang dihasilkan untuk memenuhi kebutuhan hidup. Semakin tinggi angka harapan hidup di Kab/Kota di Provinsi Jambi maka akan mengurangi tingkat kemiskinan dan sebaliknya apabila angka harapan hidup rendah maka tingkat kemiskinan akan meningkat di Kab/Kota di Provinsi Jambi.

Variabel rata-rata lama sekolah menunjukkan nilai koefisien sebesar $-0,248954$ dengan nilai probabilitas 0,3654 atau lebih besar dari $\alpha=5 \%(0,3654>0.05)$, dengan $\mathrm{t}$ statistik sebesar 0,915224 yang lebih kecil dari t tabel 1,675 maka $H_{0}$ diterima dan $H_{a}$ ditolak yang mengindikasikan bahwa variabel rata-rata lama sekolah tidak berpengaruh signifikan terhadap tingkat kemiskinan di Kab/Kota di Provinsi Jambi. Hal ini tidak sesuai dengan teori yang digunakan oleh Hutabarat (2018) yaitu variabel rata-rata lama sekolah berpengaruh negatif dan signifikan. Dan tidak sesuai dengan (Mankiw, 2012) yang menyatakan bahwa pendidikan merupakan investasi seseorang, yang apabila pendidikan seseorang tinggi maka kesejateraan sesoarang akan lebih baik. Penyebab ratarata lama sekolah tidak berpengaruh signifikan terhadap kemiskinan ini disebakan karena berdasarkan data periode 2015-2019 meskipun tingkat kemiskinan turun dan rata-rata lama sekolah meningkat namun peningkatan rata-rata lama sekolah masih dalam kategori rendah masih dibawah 12 tahun di periode tersebut. Juga disebabkan karena tidak sejalannya dengan efektifitas pemberdayaan manusia di Kab/Kota di Provinsi Jambi terlihat dari kualitas manusia yang masih menghandalkan pertanian sebagai ladang pendapatan di Provinsi Jambi. Sehingga rantai kemiskinan tidak dapat diputuskan dengan rata-rata lama sekolah.

Variabel pengeluaran perkapita menunjukkan nilai koefisien sebesar $-0,000137$ dengan nilai probabilitas 0.0002 atau lebih kecil dari $\alpha=5 \%(0.0002<0.05)$, dengan $\mathrm{t}$ statistik sebesar 4.168058 yang lebih besar dari t tabel 1,675 maka $H_{0}$ ditolak dan $H_{a}$ diterima yang mengindikasikan bahwa variabel pengeluaran perkapita berpengaruh signifikan terhadap tingkat kemiskinan di Kab/Kota di Provinsi Jambi. Tanda koefisien bernilai negatif, artinya ketika terjadi kenaikan pengeluaran perkapita sebesar Rp. 1 juta, maka tingkat kemiskinan turun sebesar 0,000137 persen. Dalam penelitian ini menunjukkan bahwa, pengeluaran perkapita berpengaruh secara signifikan dan negatif terhadap tingkat kemiskinan di Kab/Kota di Provinsi Jambi. Hasil ini sesuai dengan teori yang dikemukakan oleh Hutabarat (2018), menyatakan bahwa pengeluaran perkapita berpengaruh negatif dan signifikan terhadap tingkat kemiskinan. Karena semakin tinggi pengeluaran perkapita dapat diartikan sebagai membaiknya ekonomi masyarakat dalam memenuhi kebutuhannya. Tingkat kesejahteraan dikatakan meningkat apabila terjadinya 
kenaikan pendapatan rill yang menyebabkan meningkatnya pengeluaran perkapita rumah tangga dan mengurangi tingkat kemiskinan di Kab/Kota di Provinsi jambi.

\section{Uji hipotesis (uji F-statistik)}

Nilai F-hitung yang diperoleh dari olahan data sebesar 388,1509 lebih besar dari F-Tabel 2,77 dengan probabilitas sebesar 0,0000 atau lebih kecil dari taraf $\alpha=5 \%$ atau 0.05 , maka $H_{0}$ ditolak dan $H_{a}$ diterima. Artinya bahwa secara simultan atau bersamasama variabel angka harapan hidup, rata-rata lama sekolah dan pengeluaran per kapita berpengaruh signifikan terhadap tingkat kemiskinan di Kab/Kota di Provinsi Jambi tahun 2015-2019.

\section{Uji koefisien determinan $\left(R^{2}\right)$}

Diperoleh hasil $R^{2}$ Sebesar 0,9919 atau sebesar 99,19 persen. Ini menunjukan bahwa variabel angka harapan hidup, rata-rata lama sekolah dan pengeluaran perkapita dalam menjelaskan variabel tingkat kemiskinan adalah sebesar 99,19 persen, sedangkan sisanya sebesar 0,81 persen di jelaskan oleh variabel lain yang tidak diteliti dalam penelitian ini.

\section{Uji asumsi klasik uji multikolinieritas)}

Berdasarkan matrik korelasi untuk variabel PP AHH RLS bernilai kurang dari 0,80 . Karena nilai dari matrik korelasi dari variabel independen tidak ada yang lebih besar dari 0,80 , maka dapat dikatakan tidak terjadi multikolineritas dari ketiga variabel bebas tersebut.

Tabel 2. Matrik korelasi uji multikolinearitas

\begin{tabular}{cccc}
\hline & PP & AHH & RLS \\
\hline PP & 1 & 0.21 & 0.40 \\
AHH & 0.21 & 1 & 0.35 \\
RLS & 0.40 & 0.35 & 1 \\
\hline
\end{tabular}

Sumber: Data diolah, 2021

\section{Uji asumsi klasik (uji heterokedastisitas)}

Berdasarkan Tabel 3,Probabilita masing-masing variabel terhadap residual banyak lebih besar dari pada tingkat signifikan 5 persen sehingga dapat disimpulkan bahwa data tidak terdapat heterokedastisitas.

Tabel 3. Uji heterokedastisitas

\begin{tabular}{cc}
\hline Variable & Probabilita Residual \\
\hline C & 0,1374 \\
AHH? & 0,1497 \\
RLS? & 0,6848 \\
PP? & 0,6590 \\
\hline
\end{tabular}

Sumber: Data diolah, 2021

KESIMPULAN DAN SARAN 


\section{Kesimpulan}

Perkembangan angka harapan hidup, rata-rata lama sekolah dan pengeluran perkapita dari masing-masing Kab/Kota mengalami peningkatan. Secara keseluruhan dari $11 \mathrm{Kab} /$ Kota yang ada rata-rata tertinggi berada di Kota Jambi. Untuk tingkat kemiskinan $\mathrm{Kab} /$ Kota di Provinsi Jambi tingkat kemiskinan tertinggi berada di Kabupaten Tanjung Jabung Timur dengan tingkat kemiskinan sebesar 12,69 persen dan 11,48 persen di Kabupaten Tanjung Jabung Barat.

Model yang terbaik setelah dilakukan uji Chow dan uji Hausmant adalah Fixed effect. Secara parsial Hasil analisis variabel angka harapan hidup dan pengeluaran perkapita berpengaruh signifikan terhadap tingkat kemiskinan. Sedangkan rata-rata lama sekolah tidak berpengaruh signifikan. Secara Simultan angka harapan hidup, lama-lama rata sekolah dan pengeluaran perkapita secara bersama-sama berpengaruh signifikan terhadap tingkat kemiskinan di Kab/Kota di Provinsi Jambi.

\section{Saran}

Kepada pemerintah daerah Kab/Kota maupun pemerintah Provinsi Jambi dapat menanggulangi kemiskinan dengan meningkatkan kesejahteraan melalui tingginya angka harapan hidup, rata-rata lama sekolah. Selain itu juga harus memperhatikan hingga keplosok daerah sehingga kesejahteraan merata dan dapat mengurangi kemiskinan di Provinsi Jambi. Serta kepada peneliti lainnya, diharapkan melakukan penelitian lanjutan dengan melihat atau menambahkan variabel dan tahun penelitiannya.

\section{DAFTAR PUSTAKA}

Anggadini, Fima. (2015). Analisis Pengaruh Angka Harapan Hidup, Angka Melek Huruf, Tingkat Pengangguran Terbuka dan Pendapatan Domestik Regional Bruto Perkapita terhadap Kemiskinan pada Kabupaten/Kota di Provinsi Sulawesi Tengah Tahun 2010-2013. Jurnal Katalogis, 3(7), 40-49.

Anggoro, Risang dkk. (2020). Pengaruh Pertumbuhan Ekonomi terhadap Kemiskinan Kabupaten Tanjung Jabung Timur. E-Jurnal Perspektif dan Pembangunan Daerah, 9(1), 11-20.

Arsyad, Lincolin. (2014). Modul 1 Ekonomi Pembangunan dan Pembangunan Ekonomi. STIE YKPN: Yogyakarta.

Badan Pusat Statistik. (2020). Indeks Pembangunan Manusia (IPM) Provinsi Jambi. BPS Provinsi Jambi: Jambi

Basuki, Agus Tri. (2016). Analisis regresi dalam penelitian ekonomi dan bisnis dilengkapi aplikasi SPSS dan Eviews. Rajawali Pers: Jakarta.

Chaudhry, I. S., Malik, S., dan ul Hassan, A. (2009). The impact of socioeconomic and demographic variables on poverty: a village study., 14(1), 39.

D Chandra, S Hidayat, R Rosmeli.(2017). Dampak dana perimbangan terhadap pertumbuhan ekonomi dan ketimpangan antar daerah di Provinsi Jambi, Jurnal Paradigma Ekonomika 12 (2), 67-76

Kuncoro, M. (2010). Masalah, kebijakan, dan politik: ekonomika pembangunan. UPP STIM YKPN: Yogyakarta:

MA Alfarabi, MS Hidayat, $S$ Rahmadi. (MA Alfarabi, MS Hidayat, $S$ Rahmadi).Perubahan Struktur Ekonomi dan Dampaknya Terhadap Kemiskinan di Provinsi Jambi, Jurnal Perspektif Pembiayaan dan Pembangunan Daerah, 1 (3), 171-171

Mankiw, N.Gregory. (2012). Makro Ekonomi, Edisi keenam. Erlangga: Jakarta. 
N Nopriansyah, J Junaidi, E Umiyati . (2015). Determinan kemiskinan rumah tangga di Provinsi Jambi, Jurnal Perspektif Pembiayaan dan Pembangunan Daerah 2 (3), 119-128

Suryawati, C. (2015). memahami kemiskinan secara multidimensional. JMPK.Vol. 08, No. 03. September/2015.

Todaro, M.P. dan Smith, S.C. (2006). Pembangunan ekonomi. Jilid I Edisi Kesembilan. Haris Munandar (penerjemah). Erlangga: Jakarta.

Zamzami, D Hastuti. (2018).Determinan penerimaan daerah dan pertumbuhan ekonomi terhadap pengembangan ekonomi kreatif di Provinsi Jambi, Jurnal Paradigma Ekonomika .13 (1), 37-45 